Teachers at private universities usually do not possess tenure, and the majority are hired through contracts of less than a year. These contracts tend to be renewed, but an institution can decide not to renew a contract without notice or paying severance. As in public universities, teachers at private uni versities can be hired on hourly based contracts, part time or full time; other positions are also possible but less frequent. Private institutions possess greater flexibility to negotiate faculty salaries; for this and other reasons, salary information in private institutions is limited and difficult to study.

Teachers at private universities usually do not possess tenure, and the majority are hired through contracts of less than a year.

\section{FACULTY QUALIFICATIONS}

The minimum requirement to become a professor at a public university is a bachelor's degree. However, occasionally, people without such a degree are hired. There is no specific regulation on the minimum academic degree for private university faculty, but in general teachers have at least a bachelor's degree. Some exceptions may be found in technical institutions and programs associated with the arts. In 2005, about I.86 percent of Colombian higher education teachers had qualifications below a bachelor's degree; 36.7 percent had a bachelor's degree; and 6I percent had a postgraduate degree, including 3.3 percent holding a doctoral degree.

\section{LOOKING TOWARD 2019}

Colombia's development plan includes research and the production and application of knowledge as important components in most sectors. The draft of the education sector's 2019 strategic plan includes the goal of acquiring at least 30 percent of full-time-equivalent faculty with a doctoral degree, starting with a baseline of 8 percent of these teachers holding such a degree.

Colombia will have to create a flexible environment in public universities, improve faculty members' stability at public and private institutions, and consider competitiveness as a goal for researchers. Low salaries, precarious working conditions, and weak academic communities do not make a strong case to attract the best and the brightest to academe.

At present, just Io years away from 2019, the country should evaluate whether it will import foreign talent to improve its research capability. Given that salary plays an important role, the country should evaluate the convenience and viability of creating competitive salaries to attract Colombians and foreigners who have earned the desired qualifications to push the development plan forward. Faculty remuneration should be determined in light of the nation's vision and not only under the scope of the salaries' impact on the country's budget.

\section{Problems in China's Private Universities Osman Ozturgut}

Osman Ozturgut is the coordinator of advising and teacher certification, Division of Teaching and Learning, College of Education, University of Missouri-St. Louis, Saint Louis, Missouri, USA. E-mail: osmanhoca@hotmail.com.

A fter approval by the Beijing government, private universities began appearing in almost every major province in China. If obtaining any education is seen as the main goal, it would seem fair to say that these private colleges are providing great opportunities-given that they are accepting students with lower Chinese University Examinations scores and filling the enormous need for higher and continuing education in China. However, a focus on the quality of education (including facilities, equipment, and teaching and administrative staff) raises concern that the private colleges are not nearly as effective as even second-tier Chinese public universities.

Successful examples of private universities do exist in China (see Jing Lin and Ruth Hayhoe, "China's Private Universities: A Successful Case Study," International Higher Education, no. 5I) that are certainly providing high-quality education. However, these schools may be the exceptions, and today there are many more not-so-successful private universities in China. This article by no means intends to undermine the teaching and administration at effective institutions but attempts to provide a starting point for discussing the future of such private universities in China.

\section{INSTRUCTORS AND ADMINISTRATORS}

The instructors at private universities mainly constitute younger faculty members with bachelor's degrees and limited teaching experience. They teach 16 to 20 hours a week, with the remaining time left for chatting with other instructors, given the absence of research or professional development opportunities. The instructors usually stay at these institutions for only one or two semesters before moving on to their "real" jobs at public universities. They are paid an average salary of 2,500 RMB (around \$US350) a month and are provided a studio apartment on campus. While they pay their instructors salaries similar to those of private universities, public universities also provide job security and prestige.

The top management of the private institutions includes 
largely people from the business world with aggressive marketing experiences. Vice presidents may change three or four times during an academic year. Lower-level managers also frequently undergo shifts of positions or are transferred to different departments.

Party representatives are given executive vice president positions, with other executive management positions being filled by employing relatives. These executives, with minimal or nonexistent educational experience, view these universities as highly profitable businesses. For example, at a relatively renowned private college in Southern China, a former party secretary was hired as the executive vice president; and brothers, sisters, children, and cousins were given highly responsible jobs.

The instructors at private universities mainly constitute younger faculty members with bachelor's degrees and limited teaching experience.

\section{LIVING AND LEARNING CONDITIONS}

Facilities provided for these students, who pay around I2,000 RMB (around US\$I,750) for the year, are similar to the facilities at public universities. Students are offered mediocre living quarters in a six-student dormitory room, which includes no furniture other than a desk and stool for each student, two hours of hot water a day, no TV, and very slow (given a trend all around China) and time-limited Internet access. Student cafeterias, grocery stores, and bottled water services are usually owned and run by owners of the universities, leaving students with no other options regarding what they should eat and how much they should pay. Students may not be allowed to use cash on campus and forced instead to use school-issued debit cards, onto which they must first place a minimum of $50 \mathrm{RMB}$ at a time. This initiative is of course a matter of convenience and security, among other benefits; but the lack of a refund policy for the money unspent is a rather aggressive business strategy. Moreover, students are charged extra for Internet access, hot water usage, and electricity-occasionally three or four times more than what the Electricity Bureau charges the school-even before they use it and, again, without a refund policy. Most of these universities are located outside city centers; and with little public transportation available, students are left with no choice but to stay on campus.

Humble and desperate Chinese students, socially outcast by lower examination scores, are still willing to pay top dollar for living in mediocre quarters and being taught in classrooms without climate control (brutally hot during the summer and freezing cold during the winter) by unmotivated and inexperienced young faculty members. It should be noted that the students at these private universities receive the same living conditions offered at a public university, which charges students less than half as much as private institutions. Paying a higher tuition fee should certainly ensure better living and learning facilities, in addition to providing a global and competitive education.

\section{CONCLUSION}

The relatively low ranking of private colleges and the thus rather negative public perception of the graduates of such schools cause students to be treated as helpless customers with nowhere else to go. Recruiters make promises during recruitment fairs, focusing entirely on parental satisfaction but ignoring the needs of these students. Students go unheard, unable to complain due to the cultural barriers of losing face and disappointing their parents and relatives. Local chat rooms, while providing a platform to voice their opinions, are not significant tools to promote change in China's private universities.

These students are paying high prices and deserve better education and treatment. Instead of using the desperation of these students, China's private universities need to open their eyes to the reality of aggressive competition, from foreign joint-venture universities or other private universities. The examples in this article are based on my teaching experience at four different private colleges and universities in China, each of them with an average student population of 20,000 . One of these institutions has recently been designated by the Beijing government as among "China's Top Ten Privately Managed Educational Institutions.” These institutions should start offering more services with better training to make their students more marketable in the real world.

Again, if any education is better than no education, even these problematic private universities provide useful service to China. However, with the need for more colleges and universities in China, the low-end private universities should start focusing on giving quality education and good living conditions to students who are paying high tuition fees.

\section{Taking a Closer Look at the OECD Tertiary Statistics}

\section{Arthur M. Hauptman}

Arthur M. Hauptman is a public policy consultant based in Arlington, Virginia and specializes in higher education finance issues. E-mail: art.hauptman@yahoo.com.

The statistics that the Organization for Economic Cooperation and Development regularly reports on tertiary education in its annual Education at a Glance publication are increasingly used to compare the performance of OECD coun- 